See discussions, stats, and author profiles for this publication at: https://www.researchgate.net/publication/257991879

\title{
Projected loss of active blanket bogs in Ireland
}

Article in Climate Research · February 2014

DOI: 10.3354/cro1202

\section{CITATIONS}

11

5 authors, including:

John Coll

National University of Ireland, Maynooth

39 PUBLICATIONS 201 CITATIONS

SEE PROFILE

Micheline Sheehy Skeffington

National University of Ireland, Galway

70 PUBLICATIONS 636 CITATIONS

SEE PROFILE
READS

460

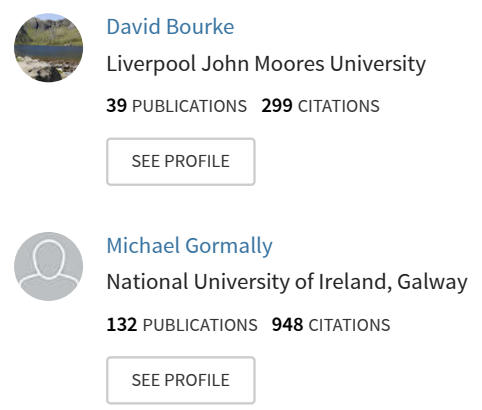

Some of the authors of this publication are also working on these related projects:

Mark-recapture of Geomalacus maculosus and Lehmannia marginata in Cloosh Forest, Ireland View project

SNH Scenarios of the Future View project 


\title{
Author note: this is a 'next of final' version. Copyright restrictions prevent public posting of the 'Climate Research' published MS.
}

\section{Projected loss of active blanket bogs in Ireland.}

\author{
John Coll $^{1 *}$, David Bourke ${ }^{2,3}$, Micheline Sheehy Skeffington ${ }^{2}$, Michael Gormally $^{3}$, \\ John Sweeney ${ }^{1}$ \\ ${ }^{1}$ Department of Geography, NUI Maynooth, Maynooth, Co Kildare, Ireland. \\ ${ }^{2}$ Botany and Plant Science, NUI Galway, Galway, Ireland. \\ ${ }^{3}$ Applied Ecology Unit, Centre for Environmental Science, NUI Galway, Galway, \\ Ireland.
}

\begin{abstract}
Active blanket bogs are ombrotrophic peatland systems of the boreo-temperate zones, although blanket peat tends to form only under the warmest and wettest of those conditions. In Europe, this is common only in Scotland and Ireland, coincident with the oceanic climate, and constitutes a significant global component of this ecosystem. Associated with this Atlantic distribution, Ireland has 50\% of the remaining blanket bogs of conservation importance within the Atlantic Biogeographic Region of Europe. It is anticipated that future climate change will place additional pressure on these systems. Active blanket bog distributions in Ireland were modelled using seven bioclimatic envelope modelling techniques implemented in the BIOMOD modelling framework. The $1961-1990$ baseline models achieved a very good agreement with the observed distribution and suggest a strong dependency on climate. The discrimination ability of the fitted models was assessed using the area under the curve (AUC; range $0.915-0.976$ ) of a receiver operating characteristic (ROC) plot. An ensemble prediction from all the models was computed in BIOMOD and used to project changes based on outputs from a dynamically downscaled climate change scenario for 2031-2060. The consistent predictions between the individual models for the baseline change substantially for the climate change projections, with losses of $82 \%$ to gains of $\sim+15 \%$ projected dependant on individual model type. However, small gains in climate space in the Midlands, east and north east of the country projected by the consensus model are unlikely to be realised as it will not be possible for new habitat to form.
\end{abstract}

Key words: Active blanket bogs, climate change, bioclimatic envelope models, BIOMOD, climate space.

† Author for correspondence. E-mail: john.coll@ nuim.ie 


\section{Introduction}

Globally, blanket bogs are rare, accounting for $\sim 3 \%$ of the total peatland area, and their distribution is restricted to temperate maritime regions typified by cool summers, mild winters and year-round rainfall (Kurbatova et al. 2009). Within the climate space associated with temperate-boreal peatlands, blanket peat tends to form under the warmest and wettest conditions (Wieder \& Vitt 2006), where precipitation is around three times greater than potential evaporation and there are no sustained dry periods. Globally, these areas typically occur in mid to high latitudes on the ocean fringes where precipitation is high and mean annual temperature range is low (Lindsay et al. 1988).

Organic matter accumulates in peat due to low decomposition rates, as a result of waterlogging and anoxia rather than high plant productivity (Malmer 1992). Blanket peat vegetation is adapted to these saturated conditions, and is highly sensitive to changes in water availability (Bragg \& Tallis 2001). In these ombrotrophic systems, high water tables are maintained by sustained precipitation and poor drainage. The reliance on precipitation makes blanket peat sensitive to climate changes that affect the net water balance (precipitation - potential evapotranspiration), as this alters the balance between decomposition and primary production (Heathwaite 1993).

Wetlands, which include blanket bogs, are important providers of ecosystem services (Maltby 2010) and specialised peatland plant species e.g. bog mosses (Sphagnum spp.) build and maintain peat. Peat provides an unusually high density of carbon storage and, where peat is forming, acts as a long-term carbon sink. More important from a contemporary carbon cycle perspective is the amount of carbon that has accumulated in peat over many millennia. Therefore, preserving existing peat stocks is an important climate mitigation strategy, even if new peat were to stop forming.

In Europe, Atlantic blanket bogs are common only in Scotland and Ireland and constitute a significant global component of this ecosystem (Sheehy Skeffington \& O'Connell 1998). Between 13.8 per cent and 17 per cent of the Irish land area is peatland, containing an estimated soil carbon stock of between 53 and 62 per cent of the national soil carbon stocks (Connolly et al. 2007; Eaton et al. 2008). Ireland's peatlands and wetlands are valued as a highly distinctive semi-natural habitat, and many have protective designations.

Irish blanket bogs are divided into two sub-categories delineated by climate and terrain: (1) Lowland Atlantic Blanket Bog or Oceanic Blanket Bog is confined to elevations of $<150 \mathrm{~m}$ (Schouten 1984), and areas with more than 250 rain d year ${ }^{-1}$ (Hammond, 1984). (2) Mountain or Upland Blanket Bog occurs in areas above 300m where annual precipitation exceeds $1250 \mathrm{~mm} \mathrm{yr}^{-1}$ (Schouten 1984).

Analysis of grid-based climate data and Irish peatland distribution identified an east-west gradient primarily related to precipitation, and a north-south gradient related to temperature (Jones et al. 2006). Although of high conservation value, only 28\% of blanket bogs in the Republic of Ireland remain in a relatively intact condition (Malone \& O'Connell 2009) due to peat extraction, drainage and forest plantation. This compares to a figure of $\sim 14 \%$ for the remaining intact blanket bog areas for Northern Ireland (Malone \& O'Connell 2009), although a small area of lowland raised bog area is incorporated in this calculation. Active Blanket Bog is listed as an Annex 1 priority habitat in the EU Habitats Directive (NPWS 2008) and Ireland has 50\% of the remaining blanket bogs of conservation importance within the Atlantic 
Biogeographic Region of Europe (Malone \& O'Connell 2009). Therefore current conservation strategies need a better understanding of these ecosystems, including the impacts of climate change. Most recently and in view of the overall status of Ireland's EU listed habitats remaining unfavourable, it has been recognised that peatland restoration is not only a priority, but that it will have to take place over a longer timescale. The global significance of Ireland's peatland resource has also recently been recognised, as has the need for all related scientific information to be synthesised to inform policy-makers (Renou-Wilson et al. 2011).

Given this close relationship between peat formation and climate, it is likely that future climate change will place additional pressure on these systems (Clark et al. 2010). Climate change is expected to result in a decrease in the summer water table in peatlands through drier summers, as well as alteration of peat-water $\mathrm{pH}$, while modification of the nutrient cycle may lead to bogs becoming net emitters of carbon (Kurbatova et al. 2009). Most bog burst and peat slide events are triggered by high magnitude rainfall events (Dykes et al. 2008) and UK and Irish data indicate that roughly half of all slippage events at present occur in the late summer months in relation to convective storm activity (Warburton et al. 2004). Therefore, more slippage events could be expected with climate change in the summer months if prior hotter and dryer conditions lead to surface cracking (Sweeney et al. 2008).

Projected increases in winter rainfall may also lead to increased peat erosion, with losses of particulate and dissolved organic carbon (POC \& DOC) from peat to surface waters (Clark et al. 2010, Yallop et al. 2010). The hydrological functioning of peat soils can influence peak river flows and flooding (Bonn et al. 2009, Holden 2009) through their influence on water retention. While some of the thermal changes projected with altitude for maritime regions (Coll et al. 2010) may also have implications for upland peat soils. The interaction between pressures such as overgrazing, draining, burning, conifer plantation and climate change could further threaten the delivery of vital services from these ecosystems. Bog habitats in Ireland are considered vulnerable when the effects of a changing climate are superimposed on other drivers of change (Jones et al. 2006).

A variety of modelling approaches have been developed and used to convert point information of species distribution into predictive maps (e.g. Araújo \& Guisan 2006; Heikkinen et al. 2006). Bioclimatic envelope models (BEMs) which can be considered as a special case of niche-based models or species distribution models (Guisan and Thuiller 2005, Heikkinen et al. 2006), are increasingly being used. BEMs correlate current species distributions with climate variables, and may then be used to project spatial shifts in species climatic envelopes according to selected climate change scenarios (Thuiller, 2003, Thuiller et al. 2004a,b). The use of BEMs for habitats is novel and only a limited number of studies have applied these methods to landforms and habitats (e.g. Fronzek et al. 2006, Parviainen and Luoto 2007, Clark et al. 2010). However, developing useful and reliable applications of BEMs requires a considerable amount of knowledge concerning the factors influencing the accuracy of model predictions (Heikkinen et al. 2006). A fundamental issue for the application of BEMs in the context of vulnerability analysis is that they can only give information about exposure to climate stress, not sensitivity (House et al. 2010). Therefore they do not provide process information, or information on feedbacks within ecosystems once the climate becomes unsuitable.

The primary aim of this study was to model the impacts of climate change for the active blanket bog priority habitat for the island of Ireland using climate and elevation variables as predictors in a BEM framework. A secondary aim was to evaluate the 
applicability of models in the BIOMOD framework (Thuiller 2003; Thuiller et al., 2009) to habitat data. Finally a consensus model based on the averaged spatial probabilities for the selected model categories was used to project changes in future climate space.

\section{Materials and Methods}

\subsection{Study area}

The study area is the whole island of Ireland that covers $\sim 84421 \mathrm{~km}^{2}$ on the Atlantic margin of northwest Europe, between $\sim 51^{\circ}$ and $56^{\circ} \mathbf{N}$. Elevations reach up to $1038 \mathrm{~m}$ above sea level (a.s.l.) (Corrán Tuathail, Co. Kerry). Much of the island is lowland, partly surrounded by mountains, with a characteristic temperate oceanic climate. Mean annual temperature (averaged over 1961 to 1990) is highest on the south-west coast $\left(10.4^{\circ} \mathrm{C}\right)$ and lowest inland $\left(8.8^{\circ} \mathrm{C}\right)$. On average, annual precipitation ranges from 750 to $1000 \mathrm{~mm}$ in the drier eastern half of the country and $>3000 \mathrm{~mm}$ $\mathrm{yr}^{-1}$ in parts of the western mountains (Rohan 1986). Active blanket bog is extensive in the west, as well as locally on mountains throughout the island.

\subsection{Data}

Distribution data for Annex I priority habitats and species were provided by the Irish National Parks and Wildlife Service (NPWS) in a GIS format. The maps are based on a combination of habitat and species distribution maps compiled from NPWS surveys (NPWS 2008). These data were complemented by data for Northern Ireland (NI) Annex I from the Joint Nature Conservancy Council database (JNCC 2007) (Figure 1). Data of this resolution are appropriate for the modelling undertaken in this study, where these have been converted to binary presence (1) and absence (0) maps on a regular $10 \times 10 \mathrm{~km}$ grid. The combined NPWS and JNCC data provided 491 cells where active blanket bog is recorded present, and 472 cells where it is recorded absent.

A quality controlled set of the 1961-1990 climate data was used to test and construct the habitat BEMs for the baseline period. These $10 \times 10 \mathrm{~km}$ resolution data are derived from observed monthly climate data for 560 precipitation stations and 70 temperature stations interpolated using a polynomial regression method with an inbuilt adjustment for elevation for the 1961-1990 baseline period (Sweeney and Fealy 2003).

Met Éireann (The Irish Meteorological Service) supplied data from the HadCM3Q16 general circulation model (GCM) dynamically downscaled to a $14 \mathrm{x} 14 \mathrm{~km}$ grid resolution via the regional atmospheric model (RCA3) (McGrath \& Lynch 2008). The output used for the impacts modelling here is for an A1B scenario from the above GCM and RCM combination. The A1B scenario projects a rise in annual temperature of 1.3 to $1.8^{\circ} \mathrm{C}$, a decrease in summer precipitation by 5 to $10 \%$ and an increase in autumn and winter precipitation by 5 to $10 \%$ by $2021-2050$ relative to the 1961-1990 baseline (McGrath \& Lynch 2008). The projected warming is greatest in the south and east of the country, whereas for precipitation there is no clear regional trend (McGrath \& Lynch 2008). The HadCM3-Q16 simulation of winter rainfall is in the intermediate to low range among the ENSEMBLES RCMs (Jacob et al. 2008).

RCA3 simulated climate data for 1961-1990 and 2031-2060 were converted to daily and monthly mean values for temperature and precipitation variables, and $\mathrm{R}$ - 
based routines (R Development Core Team, 2010) were used to re-interpolate these data to the $10 \times 10 \mathrm{~km}$ modelling grid. The climate change signal derived with respect to the RCA3 simulated 1961-1990 baseline for each 10 x $10 \mathrm{~km}$ grid cell was then applied to the observed data for the variables of interest.

\subsection{Derivation of explanatory variables}

Both the baseline climate data and the climate change signal data were converted to monthly and seasonal values for use in the BEMs. In addition to 8 climate variables, 4 variables for topography were also included (see Table S1 in the Supplement). The data range for the climate variables are provided in Table S2 of the Supplement. These data reproduce a previously identified east-west gradient primarily related to precipitation, and a north-south gradient related to temperature for Irish peatlands (Jones et al. 2006). The range of candidate explanatory variables evaluated also overlap to some extent with those reported elsewhere (e.g. Fronzek et al. 2006, Marmion et al. 2009a, Engler et al. 2011).

Mean elevation for each $10 \times 10 \mathrm{~km}$ grid cell (ArcGIS 9.3) was derived from a digital elevation model (GTOPO30) with a horizontal grid spacing of 30 arc s $(\sim 1 \mathrm{~km})$, and the range was calculated as highest minus lowest elevation in the focal cell. The data were then referenced to the climatic datasets.

\subsection{Bioclimatic envelope models}

The BIOMOD modelling framework (Thuiller, 2003; Thuiller et al., 2009) implements 9 conventional and new modelling methods, from which a selection of 7 were used in this study for the habitat modelling. The techniques included a mixture of regression methods: generalised linear models (GLM) and generalised additive models (GAM); the machine-learning methods artificial neural network (ANN), random forest (RF) and generalised boosting method (GBM); together with 2 classification methods: classification tree analysis (CTA) and flexible discriminant analysis (FDA).

A further objective in the model building process was to screen out collinearity in the covariates selected for the baseline models, this recognises that multiple regression-based approaches can be hampered by multicollinearity among predictors (Heikkinen et al. 2006). BIOMOD can usefully specify non-linear terms for GLM in particular, thereby opening up many more candidate covariate possibilities. However, there is no screen for collinearity among predictors in BIOMOD per se. Therefore a combination of correlation matrices and principal components analysis (PCA) were used to screen the available covariates beforehand, and any collinear terms were excluded from the final covariate selection used in the BIOMOD modelling. There was also some a posteriori knowledge of where collinearity in the covariates was probable based on previous work (Coll et al. 2011, 2013).

For all 7 models, the variables used were; annual temperature range (ATR), mean winter precipitation (MWP) and temperature (MWT), elevation range (Range) and mean elevation (Mean). Once the variables are selected, the individual models in BIOMOD use internal measurements, based on either stepwise regression or classification error rates; the Akaike information criterion (AIC) statistic is also evaluated internally and the model with the lowest AIC chosen. BIOMOD also provides an assessment of variable importance based on the extent to which model predictions change when a given variable is randomised (Thuiller et al. 2009). 
We emphasise caution not to interpret too much in relation to which variables were included or not, as in any multivariate model-building process, producing a single model can be dubious (Mac Nally 2000). This is particularly true when the candidate explanatory variables are numerous and the potential causal relationships between them and the response variable are not well known $a$ priori.

In order to measure changes in climatic suitability for the habitat rather than interpreting model projections as estimates of the changes in observed habitat distributions, an 'unlimited dispersal' scenario was adopted, whereby the habitat is assumed to be able to track shifting suitable climate over the entire study area. We recognize that this is unrealistic for habitat modelling in particular, but the choice reflects a desire to assess the potential change in the overall climate space for the active blanket bog habitat in Ireland.

\subsection{Model predictive performance}

Projections of the probability of occurrence for each individual model were based on a threshold maximizing the TSS, a commonly used threshold because it produces the most accurate predictions (Allouche et al. 2006). Model accuracy was also assessed with the area under the curve (AUC) from receiver operating characteristic (ROC) plots (Fielding \& Bell 1997). Although AUC has been criticised recently (e.g. Lobo et al. 2008), it still provides an informative measure of model discriminatory performance (Reineking and Schröder, 2006).

Each individual model in BIOMOD assesses the contribution of the predictor variables to the model, and with a permutation procedure it is possible to extract a measure of the relative importance of each variable. Once the models are calibrated, a standard prediction is made and then one of the variables is randomised and a new prediction made. The correlation score between that new prediction and the standard prediction is calculated and is considered to give an estimation of the variable importance in the model (Thuiller et al. 2009).

BIOMOD also allows the calculation of an ensemble prediction from all the models, reducing the uncertainties arising from using only a single model. It provides several methods to calculate the ensemble, such as probability mean and weighted mean. A PCA of the median value was used and is calculated on the probabilities given by the models. This ranks the models according to their predictive performance and in the version of BIOMOD used here, the consensus model is the model whose projection is the most correlated with the first axis of the PCA (Thuiller et al. 2009). It is considered to be more reliable because it is less influenced by extreme values (Thuiller et al. 2009), and a decay weighting of 1.6 was used. The decay gives the relative importance of the weights; e.g. a decay of 1 is equivalent to a committee averaging whereby the same weights are given to all the elements. 


\section{Results}

\subsection{Model performance and the importance of variables}

The predicted baseline distributions obtained for all the BIOMOD active blanket bog models have good TSS values (0.711 - 0.978), Kappa values (0.711 - 0.978); and AUC range of values (0.915 - 0.976) (Table 1). This consistent performance between the models for the baseline is reflected in the mean predicted probability for each model type, which is not the case for the climate change projections, where there are substantial differences in the mean probabilities (Figure 2).

For the active blanket bog modelling, there is again consistency between the BIOMOD models in relation to the variable importance. Across the models, Range and MWP emerge as consistently important, although the relative importance of each varies between the models according to the influence of the other covariates in each individual model type (Figure 3).

\subsection{Comparison of baseline and projected climate space}

A comparison of the mapped predictions for the baseline period from the 7 BIOMOD models with the observed distribution indicate that the pattern of the spatial distribution of active blanket bog is well captured in all models, with incorrect predictions mainly occurring in individual grid cells at the margins of the observed active blanket bog distribution (Figures $\mathrm{S} 1-7$ in the Supplement).

By contrast, when the A1B scenario climate change data is projected through the models, the results differ substantially between the different models. The GLM and FDA models project the greatest potential loss of climate space compared to the baseline (Table 2, see Figures S1 \& S7 in the Supplement). The GAM and ANN models project substantial potential losses of climate space (Table 2, see Figures S2 \& S3 in the Supplement); while the GBM model projects moderate losses (Table 2, see Figure S4 in the Supplement), and the RF and CTA models project some potential gains in climate space relative to the baseline (Table 2; see Figures S5 \& S6 in the Supplement).

The BIOMOD ensemble projections indicate an overall loss of suitable climate space for active blanket bog, although a number of areas remain stable and some gains are also projected (Figure 4). The projected changes indicate the greatest loss of climate space to be in the south and west of the country; the most substantial losses are associated with low-elevation cells on the coast, and in the west and south-west away from the mountains. Overall therefore, the models project most losses of suitable climate space for low-lying southern and western cells in particular, whereas they indicate some preservation of suitable climate space for upland areas in these regions. The projected expansions of climate space are primarily in the Midlands, the east and the north-east. The role of elevation as an important control on the distribution of future climate space within the models is emphasised in Figure 5, where the highest counts of stable $10 \times 10 \mathrm{~km}$ cells are associated with higher mean elevations (Figure 5a) and a greater elevation range (Figure 5b). 


\section{Discussion}

\subsection{Consensus modelling}

Discrimination and calibration are two different but complementary measures of model performance, so it has been suggested that both should be used in combination (Harrel 2001). The different discrimination measurements are subject to debate (e.g., Fielding \& Bell 1997, Guisan \& Thuiller 2005), and there is no generally accepted measure of performance for binary models (Pearce \& Ferrier 2000).

Although not directed at this specific issue, the use of consensus methods are becoming increasingly popular on the basis that they decrease the predictive uncertainty of single-models by combining their predictions (Marmion et al., 2009b; Grenouillet et al., 2011). Also, due to the variation in the performance of different model types, averaging the results of individual models may increase the overall accuracy of predictions (Araújo \& New 2007). Model averaging can be performed by weighting the individual model projections, by their AUC or TSS scores and averaging the result, a method shown to be particularly robust if a number of model families are to be evaluated (Marmion et al. 2009b). In this context, the ensemble prediction provided by BIOMOD is particularly useful in reducing the uncertainties associated with any given single model.

\subsection{Modelling current distribution}

Climatic variables used to determine blanket peat bioclimatic space include temperature, growing degree days, precipitation and water balance (precipitation minus potential evaporation) (Clark et al. 2010). Precipitation has been shown to be more important than temperature in explaining blanket bog distribution in Fennoscandia (Parviainen \& Luoto 2007). In the UK, number of days with rainfall was considered to be more important than total precipitation in explaining blanket peat distribution (Clark et al. 2010). This is most likely because the number of rain days has been linked with Sphagnum moss growth and primary production (Backeus 1988). Maximum temperature is thought to be the main factor limiting the distribution of upland montane plant species in Britain (Rodwell et al. 1992), although in the absence of maximum temperature data, mean temperature has been used to explain blanket peat distribution (Hossell et al. 2000).

Overall the presented climate-based models for the distribution of active blanket bogs successfully replicated the observed distribution across Ireland. The models are therefore useful predictors. In general, climate is the primary controlling environmental factor in the distribution of active blanket bogs at the geographical scale modelled here; although elevation range through its influence on both temperature and precipitation is also an important variable in the models.

MWP and Range emerge as the key variables in all the categories of model, although their relative importance in relation to the other covariates specified varies between the models. The influence of using elevation range in the models supports results showing that the inclusion of topographical variables improves the predictive accuracy of models for this habitat (Coll et al. 2011), which is also the case for European butterfly species (Luoto \& Heikkinen 2008). Climatic and topographical gradients are known to operate at different spatial scales, with the latter nested in the 
former (Bruun et al. 2006), so the inclusion of the elevation data in this study provides a more local component for all the models. Furthermore, elevation range has been commonly used as a surrogate for environmental and climatic heterogeneity within grid cells in species richness modelling studies, as topographical heterogeneity compresses biotic communities into more constricted vertical spaces (e.g. Coblentz \& Riitters 2004) and effectively mingles habitat types and species that are otherwise often widely spatially separated.

Precipitation and elevation (through its influence on temperature) are known to be key controls on the habitat distribution in the present, and their importance as covariates in the models here reflect earlier findings in relation to the key controls on the active blanket bog habitat distribution (Jones et al. 2006). Hence the future changes in climate space projected for the habitats and their associated communities and species in response to the changes in precipitation and winter temperature make sense both biogeographically and topographically at the finer scale of analysis presented here for Ireland. This has major implications for the type of blanket bog most vulnerable to a loss of climate space, since the areas coincident with the greatest loss of suitable climate space are associated with the lowland blanket bog distribution along the western Atlantic seaboard.

\subsection{Modelling the effect of climate change on active blanket bog distribution}

A reduction in the climate space associated with blanket peat in the current study is consistent with projections using a GLM model based on mean temperature for the UK (Hossell et al. 2000), but differs from other studies of the region, where BEMs based on ANNs using measures of soil water deficit and surplus, as well as maximum and minimum temperature showed little overall change in blanket bog habitat under the same United Kingdom Climate Impacts Programme 1998 (UKCIP98) scenarios (Berry et al. 2003). UK-based modelling also indicates that the combination of temperature and precipitation variables is important in BEMs for blanket peat. It was found, for example, that models which included measures of both hydrological conditions and maximum temperature provided a better fit to the mapped peat area than models based on hydrological variables alone (Clark et al. 2010). In light of this, it is surprising that the influence of MWT was not more substantial in the models developed and applied here. However, given the clear importance of elevation range in all the models, it is possible that it served as a proxy for some of the other seasonal temperature terms which could have been included.

The significance of temperature in comparison to precipitation and water deficit in controlling peatland surface wetness has also been more widely debated recently, with contrasting views (Barber \& Langdon 2007, Charman et al. 2009, Booth 2010). However, it remains unclear whether climatic variables driving shorter-term water table fluctuations (i.e. water deficit or annual accumulated monthly water deficit) or longer term measures of surface wetness (i.e. maximum or summer temperature) are more important for net peat accumulation in terms of the relative influence on peatland vegetation and structure relative to net organic matter decomposition (Clark et al. 2010). Nevertheless, combinations of winter precipitation and winter temperature alongside the terrain variables parsimoniously captured the habitat distribution here. 


\subsection{Limitations and assumptions of the methods}

The limitations and assumptions involved in using a $10 \times 10 \mathrm{~km}$ grid are well known. Important controlling variables such as topographic and environmental heterogeneity will be lost at this resolution, together with important local microclimatic controls. A key limitation is the lack of both data and resolution to discern the differences between lowland and upland blanket bog. This is critical, as the former is much rarer at a European scale (Sheehy Skeffington \& O'Connell, 1998). For similar scale-dependant reasons no account can be taken of the relative coherence or patchiness of the active blanket bog habitat within individual grids where the community presence is recorded. An obvious but important point in relation to the active blanket bog habitats, is that projected changes in the climate space associated with the current distribution of active blanket bog are not the same as projecting changes in the actual distribution over the next century. It has been suggested that blanket peat habitats, even if not in a state of active growth, could well persist over decades or longer despite a reduction in climate space (Clark et al. 2010).

The BEMs presented here are based on derived statistical relationships between the known mapped distribution of active blanket bog habitats and climatic variables; it is not known whether this mapped distribution represents active blanket bog in an equilibrium state with current climate. It is therefore possible that the calibrated baseline models do not fully capture the climate envelope reflecting sustainable conditions for the active blanket bog habitat presence. In addition, the caveat which applies to BEMs in general must remain: compared to process-based simulation models, BEMs are intuitive but also simplistic (Jeschke \& Strayer, 2008). BEMs couple presence-absence data to derive a multivariate and correlative characterisation of the abiotic ecological niche based upon current distributions and use this to predict the available climate space under scenarios of global warming. This assumes that distributions are principally determined by intrinsic physiological tolerances relating to temperature, moisture etc., a longstanding view in ecology captured in the fundamental niche concept; whereas the realised niche is essentially the net occupancy range after accounting for biotic effects (Hutchinson 1957). However, as BEMs utilise observed ranges for their estimates, they use realised distributions to predict future distributions. Nevertheless, and despite the criticisms, BEMs and other models are providing an ever-better understanding of the mechanisms by which species and ecosystems are affected by climate change, and tremendous improvements are being made in virtually all aspects of this emerging field (Bellard et al. 2012).

The final variables selected in the models reflect 2 primary properties of climate that are key factors affecting species and habitat distribution: temperature and water (e.g. Whittaker et al. 2007). However, other important environmental information is omitted in the models. Blanket peat tends to form on impermeable rocks or thick layers of glacial till on shallow slopes (typically $<10^{\circ}$ ) where saturated conditions are allowed to develop because of impeded and/or slow drainage (Taylor 1983). Therefore there is scope to refine the models by the inclusion of more refined topography and land cover variables; obvious candidates for the active blanket bog habitats would be further information on slope angle and aspect, which through their controls on light regimes influence evapotranspiration. For example, differences in light regimes between north- and south-facing aspects in temperate latitudes can produce differences in temperature equivalent to a move of $\sim 200 \mathrm{~km}$ polewards (Austin \& van Neill 2011). It has also been widely reported that the influence of 
local topography may create critical climatic refugia that are important even in studies of very large areas (Coll 2010, Austin \& Van Neill 2011). Consequently, there is scope to incorporate more refined measures in future models which better capture the influence of topography in creating the conditions necessary for the persistent rainfall which supports blanket bog formation. However, prior to and throughout the modelling process we critically considered key assumptions and rigorously evaluated covariate selection based on the data available. In this sense, we consider that the results are presented in an appropriate conceptual context (sensu Araújo \& Townsend Peterson 2012).

\subsection{Implications of changing climate space for bog distributions}

The projected decline in the climate space associated with active blanket bog areas can be expected to have significant implications for the ecology of these complex wetland ecosystems and their associated plant and animal species adapted to live in the wet, nutrient-poor, conditions. Seasonal drying for example may affect surface micro-topography and hydrology. This in turn will influence the plant composition and habitat suitability for birds and other species. Loss of unprotected high quality wetlands such as active blanket bog will result in the direct loss of wetland biodiversity by physical removal of the habitats and most plant and invertebrate species, while degradation may cause reduced species diversity and local extinction of rare or sensitive species (Scally et al. 2010). Such a climate change-driven degradation and loss may have secondary impacts on the biodiversity value of the remaining bog areas through increased isolation and fragmentation of the remaining habitat. Degrading bogs will also have an impact on the climate through changes in the peatland $\mathrm{CO}_{2}$ and methane $\left(\mathrm{CH}_{4}\right)$ dynamics.

\section{Conclusions and implications for future work}

Our results indicate that the distribution of active blanket bog in Ireland is regionally sensitive to climate change, most notably for lower-lying areas in the south and west of the country. Increasing temperature and precipitation changes will reduce the area that is suitable for active blanket bog development. This could have major implications for the lowland blanket bog distribution along the western Atlantic seaboard where the projected losses are greatest. Offsetting these losses are the minor climate space gains in the Midlands and the north east, and some retention of suitable climate space in upland areas in the south and west. It should, however, be emphasised that it will not be possible for new habitat to form. These changes may proportionately affect lowland more than upland blanket bog, with critical conservation policy implications. Further degradation as result of climate change may also result in peatlands becoming carbon source ecosystems with the potential to lose carbon either as trace gases such as carbon dioxide $\left(\mathrm{CO}_{2}\right)$ and methane $\left(\mathrm{CH}_{4}\right)$ or fluvial dissolved organic carbon (Koehler et al. 2010).

Incorporating more detailed information into the BEMs can further improve confidence and reduce uncertainty in model estimates for the future distribution of Irish blanket bogs. Specifically information such as bog type and altitude at a finer scale could better inform us on active blanket bog status and type. Other information 
concerning e.g. underlying drift, soil conditions, and slope angle and aspect may improve model results. The distribution models presented here should be applicable to blanket bog regions outside Ireland, so long as data for the evaluation of the estimates is available.

Some attempt has been made to deal with uncertainty, at least in relation to differing results between the model categories, by providing the results from the individual BEMs implemented in the BIOMOD framework alongside the ensemble projection. Certainly there is substantial variation in the results between the individual BEM types when the AIB scenario data is projected through the models. Although only the downscaled output from one GCM and scenario has been used to project climate space changes here, the methods lend themselves to using different GCM and RCM outputs from a range of scenarios (e.g. Fronzek et al. 2011; Garcia et al. 2012) and from different GCMs to better encapsulate uncertainty. Given the importance of mean winter precipitation in all the BEM model families, had a wetter or dryer model or scenario been used from the ENSEMBLES RCMs, the results projected via the BEMs could have varied further. However, it is also worth noting that more comprehensive weighting approaches to climate model output which also incorporate model skill in areas beyond the mean climate state are required even in domain-specific investigations (Foley et al. 2013).

Overall, such an expanded framework would allow the identification of adaptation strategies that are robust (i.e. insensitive) to climate change uncertainties, and would allow more confidence in identifying and targeting vulnerable areas of blanket bog for priority conservation management measures. However, future research could also integrate such a scenarios-impacts (top-down) approach alongside a vulnerabilitythresholds (bottom-up) approach. Rather than trying to predict impacts through individual scenarios, such an integrated approach would help to better identify critical thresholds for climate change vulnerabilities alongside the multiple other drivers of change in these sensitive systems. 
Acknowledgements. We thank: the technical and scientific support staff at NPWS (Ireland) for supplying the GIS habitat maps for Irish priority habitats and species; Graham French at the National Biodiversity Network (UK) for supplying the GISenabled Irish Grid data and Steve Wilkinson at the Joint Nature Conservancy Council (UK) for the priority habitats and species database containing the NI records. We also thank Ray McGrath and Tido Semmler at Met Éireann for providing the c4i climate change data. J.C. would also like to thank his ICARUS colleagues R. Teck and C. Holman for their input in processing the climate change data; and A. Ralph and S. Bastola for their helpful discussions on some of the statistical elements of the modelling. D.B. would like to thank the Royal Irish Academy for awarding a Mobility Grant which enabled his visit to Laboratoire d'Ecologie Alpine, CNRS and Université Joseph Fourier, Grenoble, France to collaborate with Dr W. Thuiller and his team on the application of BIOMOD to undertake the climate change and biodiversity modelling. Without all of their goodwill, assistance and support, our progress in the methods developed here for Ireland would not have been possible. This research was supported by the Irish Environmental Protection Agency (EPA) under grants 2007CCRP-2.26 and 2010-CCRP-DS-2.3. We would also very much like to thank the 2 anonymous reviewers who provided valuable feedback and comment on the original manuscript. 


\section{References}

Allouche O, Tsoar A, and Kadmon, R (2006) Assessing the accuracy of species distribution models: prevalence, kappa and the true skill statistic (TSS). J Appl Ecol 43: 1223-1232

Araújo MB, Guisan A (2006) Five (or so) challenges for species distribution modelling. J Biogeogr 33,1677-1688

Araújo MB, New M (2007) Ensemble forecasting of species distributions. Trends Ecol Evol 22, 42-47

Araújo MB, and Townsend Peterson A (2012) Uses and misuses of bioclimatic envelope modelling. Ecol 93(7): 1527-1539

Austin MP, Van Niel KP (2011) Improving species distribution models for climate change studies: variable selection and scale. J Biogeogr 38: 1-8

Backeus I (1988) Weather variables as predictors of Sphagnum growth on a bog. Hol Ecol 11:146-150

Barber KE, Langdon PG (2007) What drives the peat-based paleoclimate record? A critical test using multiproxy climate records from northern Britain. Quat Science Review 26: 3318-3327

Bellard C, Bertelsmeier C, Leadley P, Thuiller W, Courchamp F (2012) Impacts of climate change on the future of biodiversity. Ecol Lett 15: 365-377

Berry PM, Dawson TP, Harrison PA, Pearson R, Butt N (2003) The sensitivity and vulnerability of terrestrial habitats and species in Britain and Ireland to climate change. J Nature Conservation 11:15-23

Bonn A, Allott T, Hubacek K, Stewart, J (2009) Drivers of environmental change in upland environments. Routledge, Abingdon

Booth RK (2010) Testing the climate sensitivity of peat-based paleoclimate reconstructions in mid-continental North America. Quat Science Review 29:720 731

Bragg OM, Tallis JH (2001) The sensitivity of peat-covered upland landscapes. Catena 42: $345-360$

Bruun HH, Moen J, Virtanen R, Grytnes JA, Oksanen L and Angerbjorn A (2006) Effects of altitude and topography on species richness of vascular plants, bryophytes and lichens in alpine communities. J Veg Sci: 17 37-46

Charman DJ, Barber KE, Blaauw M, Langdon, PG and others (2009) Climate drivers for peatland palaeoclimate records. Quat Science Review 28:1811-1819

Clark JM, Gallego-Sala AV, Allott TEH, Chapman SJ and others (2010) Assessing the vulnerability of blanket peat to climate change using an ensemble of statistical bioclimatic envelope models. Clim Res 45:131-150

Coblentz DD, Riitters KH (2004) Topographic controls on the regional-scale biodiversity of the south-western USA. J Biogeogr 31: 1125-1138

Coll J (2010) Climate Change and Europe's Mountains. In: Price, MF (ed) Europe's ecological backbone: recognising the true value of our mountains. European Environment Agency (EEA) Report No 6/2010

Coll J, Bourke D, Sweeney J, Gormally, M, Sheehy Skeffington M (2011) Developing a predictive modelling capacity for a climate change vulnerable blanket bog habitat: Assessing baseline climate relationships. Ir Geog 44:1, 27-60

Coll J, Bourke D, Gormally M, Sheehy Skeffington M, and Sweeney J (2013) Climate change impacts on biodiversity in Ireland: Projecting changes and informing adaptation measures. Environmental Protection Agency CCRP Report No. 19. Wexford 
Coll J, Gibb SW, Price MF, McClatchey J, Harrison J (2010). Developing site scale projections of climate change in the Scottish Highlands. Clim Res 45:71-85

Connolly J, Holden N, Ward S (2007) Mapping peatlands in Ireland using a rulebased methodology and digital data. Soil Sci Soc Am J 71, 492-499

Dykes AP, Gunn J, Convery KJ (2008) Landslides in blanket peat on Cuilcagh Mountain, northwest Ireland. Geomorphology 102 (3-4): 325-340

Eaton JM, McGoff NM, Byrne KA, Leahy P and Kiely G (2008) Land cover change and soil organic carbon stocks in the Republic of Ireland 1851-2000. Clim Chang 91: 317-334

Engler R, Randin CF, Thuiller W, Dullinger S and others (2011) 21st century climate change threatens mountain flora unequally across Europe. Glob Change Biol 17: 2330-2341

Fielding A, Bell JF (1997) A review of methods for the assessment of prediction errors in conservation presence/absence models. Environ Conserv 24:38-49

Foley A, Fealy R, Sweeney J. (2013) Model skill measures in probabilistic regional climate projections for Ireland. Clim Res 56: 33-49

Fronzek S, Carter TR, Luoto, M (2011) Evaluating sources of uncertainty in modelling the impact of probabilistic climate change on sub-arctic palsa mires. Nat. Hazards Earth Syst Sci 11: 2981-2995

Fronzek S, Luoto M, Carter TR (2006) Potential effect of climate change on the distribution of palsa mires in subarctic Fennoscandia. Clim Res 32: 1-12

Garcia RA, Burgess ND, Cabeza M, Rahbek C, Araújo MB (2012) Exploring consensus in 21 st century projections of climatically suitable areas for African vertebrates. Glob Change Biol 18 (4), 1253-1269

Grenouillet G, Buisson L, Casajus N, Lek S. (2011) Ensemble modelling of species distribution: the effects of geographical and environmental ranges. Ecography 34:9-17

Guisan A, Thuiller W (2005) Predicting species distributions: offering more than simple habitat models. Ecol Lett 9: 993-1009

Hammond RF (1984) The Classification of Irish peats as surveyed by the National Soil Survey of Ireland. 7th International Peat Congress, Dublin

Harrell EE (2001) Regression Modeling Strategies. Springer- Verlag, New York

Heathwaite AL (1993) Disappearing peat - regenerating peat: the impact of climate change on British peatlands. Geo Journal 159: 203-208

Heikkinen RK, Luoto M, Araújo MB, Virkalla M, Thuiler W and Sykes MT (2006) Methods and uncertainties in bioclimatic envelope modelling under climate change. Prog Phys Geog 30(6): 751-777

Holden J (2009) Upland hydrology. In: Bonn A, Allott T, Hubacek K, Stewart J (eds) Drivers of environmental change in uplands. Routledge, London

Hossell JE, Briggs B, Hepburn IR (2000) Climate change and UK nature conservation: a review of the impact of climate change on UK species and habitat conservation policy. Department of the Environment, Transport and the Regions, London

House JI, Orr HG, Clark JM, Gallego-Sala AV, Freeman C, Prentice C, Smith P (2010) Climate change and the British Uplands: evidence for decision making. Clim Res 45: 3-12

Hutchinson GE (1957) Concluding remarks. Population studies: Animal ecology and demography. Cold Spring Harbor Symp. Quantative Biology 22:415-427

Jacob D, Bøssing Christensen O, Doblas-Reyes FJ, Goodess C and others (2008). Information on observations, global and regional modelling data availability and statistical downscaling. ENSEMBLES Technical Report No 4 
(http://ensemblesrt3.dmi.dk/quicklook/quicklook.html. Last Accessed, October 2013)

Jeschke JM, Strayer DL (2008) Usefulness of Bioclimatic Models for Studying Climate Change and Invasive Species. Ann N Y Acad Sci 1134: 1-24

JNCC (2007) Second Report by the UK under Article 17 on the implementation of the Habitats Directive from January 2001 to December 2006. Joint Nature Conservation Committee, Peterborough

Jones MB, Donnelly A, and Albanito, F (2006) Responses of Irish vegetation to future climate change. Biol Environ 106B(3): 323-334

Koehler A, Sottocornola M and Kiely G (2011) How strong is the current carbon sequestration of an Atlantic blanket bog? Glob Change Biol 17, 309-319

Kurbatova J, Li C, Tatarinov F, Varlagin A, Shalukhina N, Olchev A (2009) Modeling of the carbon dioxide fluxes in European Russia peat bogs Environ Res Lett , 4 (4): 1-5

Lindsay RA, Charman DJ, Everingham F, O'Reilly RM, Palmer MA, Rowell TA, Stroud DA (1988) The flow country: the Peatlands of Caithness and Sutherland. Nature Conservancy Council, Peterborough

Lobo JM, Jimenez-Valverde A, Real R (2008) AUC: a misleading measure of the performance of predictive distribution models. Glob Ecol Biogeogr 17: 145-151.

Luoto M, Heikkinen RK (2008) Disregarding topographical heterogeneity biases species turnover assessments based on bioclimatic models. Glob Change Biol 14: 483-494

MacNally R (2000) Regression and model-building in conservation biology, biogeography and ecology: the distinction between - and reconciliation of 'predictive' and explanatory models. Biodivers Conserv 9: 655-671

Malmer N (1992) Peat accumulation and the global carbon cycle. In: Boer M, Koster, E (eds) Greenhouse-Impact on Cold-Climate Ecosystems and Landscapes. Selected papers of the European Conference on Landscape Ecological Impact of Climatic Change. Lunteren, The Netherlands. Catena Supplement 22:97-110

Malone S, O'Connell C (2009) Ireland's Peatland Conservation Action Plan 2020 halting the loss of peatland biodiversity. Irish Peatland Conservation Council, Kildare

Maltby E (2010) Effects of climate change on the societal benefits of UK upland peat ecosystems: applying the ecosystem approach. Clim Res 45: 249-259

Marmion M, Luoto M, Heikkinen RK, Thuiller W (2009a) The performance of state-of-the-art modelling techniques depends on geographical distribution of species. Ecol Model 220: 3512-3520

Marmion M, Parviainen M, Luoto M, Heikkinen R, Thuiller W (2009b) Evaluation of consensus methods in predictive species distribution modelling. Diversity and Distributions 15: 59-69

McGrath R, Lynch P (eds) (2008) Ireland in a Warmer World: Scientific Predictions of the Irish Climate in the Twenty-First Century. Community Climate Change Consortium for Ireland (C4I), Dublin

NPWS (2008) The Status of EU Protected Habitats and Species in Ireland. National Parks and Wildlife Service, Department of the Environment, Heritage and Local Government, Dublin

Parviainen M, Luoto M (2007) Climate envelopes of mire complex types in Fennoscandia. Geogr Ann A 89A:137-151

Pearce J, Ferrier S (2000) Evaluating the predictive performance of habitat models developed using logistic regression. Ecol Model 133: 225-245 
R Development Core Team (2010). CRAN R Library repository. Available at: http://cran.r-project.org/.

Reineking B and Schröder, B (2006) Constrain to perform: Regularization of habitat models. Ecol Model 193(34): 675-690

Renou-Wilson F, Bolger T, Bullock C, Convery F and others (2011) BOGLAND: Sustainable Management of Peatlands in Ireland. EPA STRIVE Report Series No 76. Wexford

Rodwell JS, Pigott CD, Ratcliffe DA, Malloch AJC and others (1992) British plant communities, Vol 3. Grasslands and montane communities. Cambridge University Press, Cambridge

Rohan PK (1986) The climate of Ireland. The Stationery Office, Dublin

Scally L, Waldren S., Atalah J, Brown, M. and others (2010) Biodiversity and Environmental Change an Integrated Study Encompassing a Range of Scales, Taxa and Habitats (Biochange). Draft Technical Project Report. Environmental Protection Agency, Wexford

Schouten MGC. (1984) Some Aspects of the Ecogeographical Gradient in the Irish Ombrotrophic Bogs. Proceedings of the 7th International Peat Congress, Dublin

Sheehy Skeffington MJ, O'Connell C (1998) Peatlands of Ireland. Studies in Irish Limnology. In: Giller, P (ed) Societas Internationalis Limnologiae (SIL). Dublin

Sweeney J, Fealy R. (2003) Establishing Reference Climate Scenarios. In: Sweeney, J (ed) Climate Change Scenarios and Impacts For Ireland. Environmental Protection Agency. ERTRI Report 15, Dublin

Sweeney K, Fealy R, McElwain L, Siggins L, Sweeney J, Trinies T. (2008). Changing Shades of Green: The environmental and cultural impacts of climate change in Ireland. California, The Irish American Climate Project \& Rockefeller Family Fund, New York

Taylor JA (1983) The peatlands of Great Britain and Ireland. In: Gore AJP (ed) Ecosystems of the world, Vol. 4B; mires: swamp, bog, fen and moor. Elsevier, Amsterdam

Thuiller W (2003) BIOMOD - optimizing predictions of species distributions and projecting potential future shifts under global change. Glob Change Biol 9: 13531362

Thuiller W. (2004a) Patterns and uncertainties of species' range shifts under climate change. Glob Change Biol 10: 2020-2027

Thuiller W, Araújo, MB and Lavorel S (2004b) Do we need land-cover data to predict species distributions in Europe? J Biogeogr 31: 353-361

Thuiller W., Lafourcade, B., Araujo, M. (2009) Model Operating Manual for BIOMOD. Universite Joseph Fourier, Grenoble

Warburton J, Holden J, Mills AJ (2004) Hydrological controls of surficial mass movements in peat. Earth Sci Rev 67(1-2): 139-156

Whittaker RJ, Nogues-Bravo D and Araújo MB (2007) Geographic gradients of species richness: a test of the water-energy conjecture of Hawkins et al. (2003) using European data for five taxa. Global Ecol Biogeogr 16: 76-89

Wieder R., Vitt DH (2006) Boreal peatland ecosystems. Springer, Berlin

Yallop AR, Clutterbuck B, Thacker J (2010) Increases in humic dissolved organic carbon export from upland peat catchments: the role of temperature, declining sulphur deposition and changes in land management. Clim Res 45: 43-56 


\section{Figures}

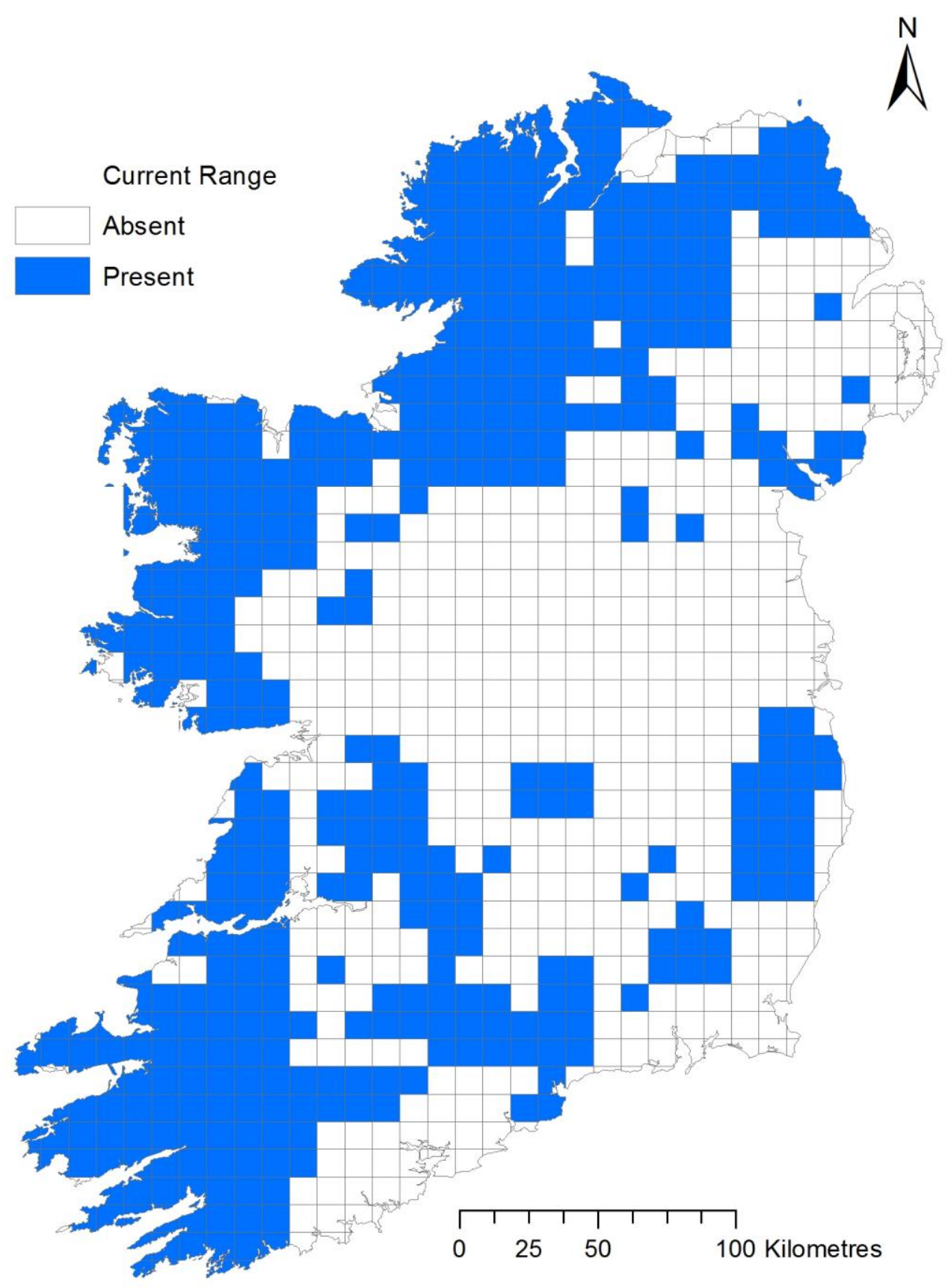

Figure 1. Current distribution of active blanket bog in Ireland based on National Parks and Wildlife Service data (Ireland) and Joint Nature Conservancy Council data (Northern Ireland). Squares: habitat presence (blue) or absence (white) squares. 


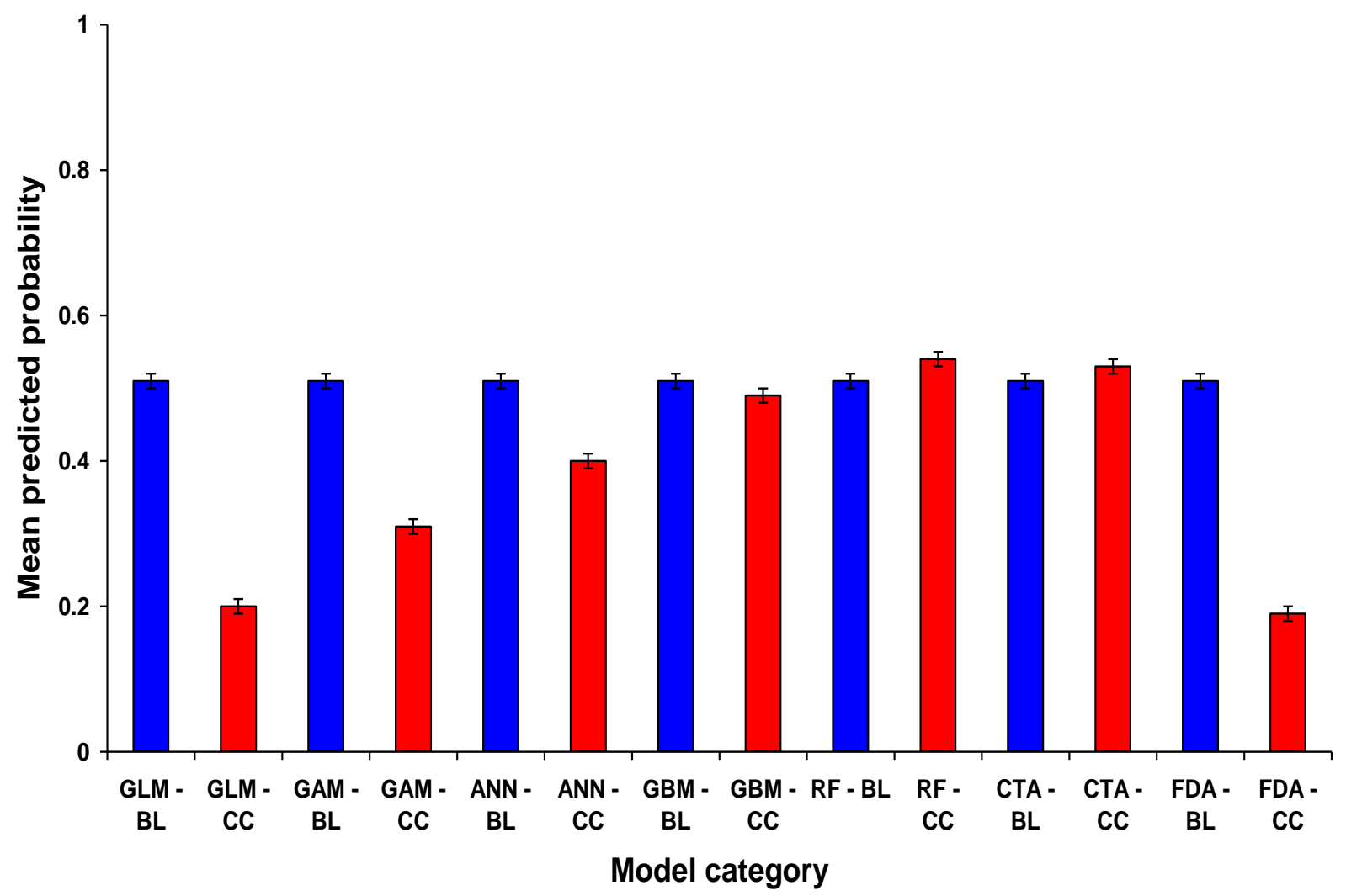

Figure 2: Summary comparison of the predictive performance of the 7 models implemented in BIOMOD illustrating the mean probability distribution shifts associated with the climate change projections (CC; 20131-2060) compared to the baseline. (BL;1961-1990) baseline mean probability prediction for each model type. Vertical bars: +/- SE. See Table 1 for model acronyms 


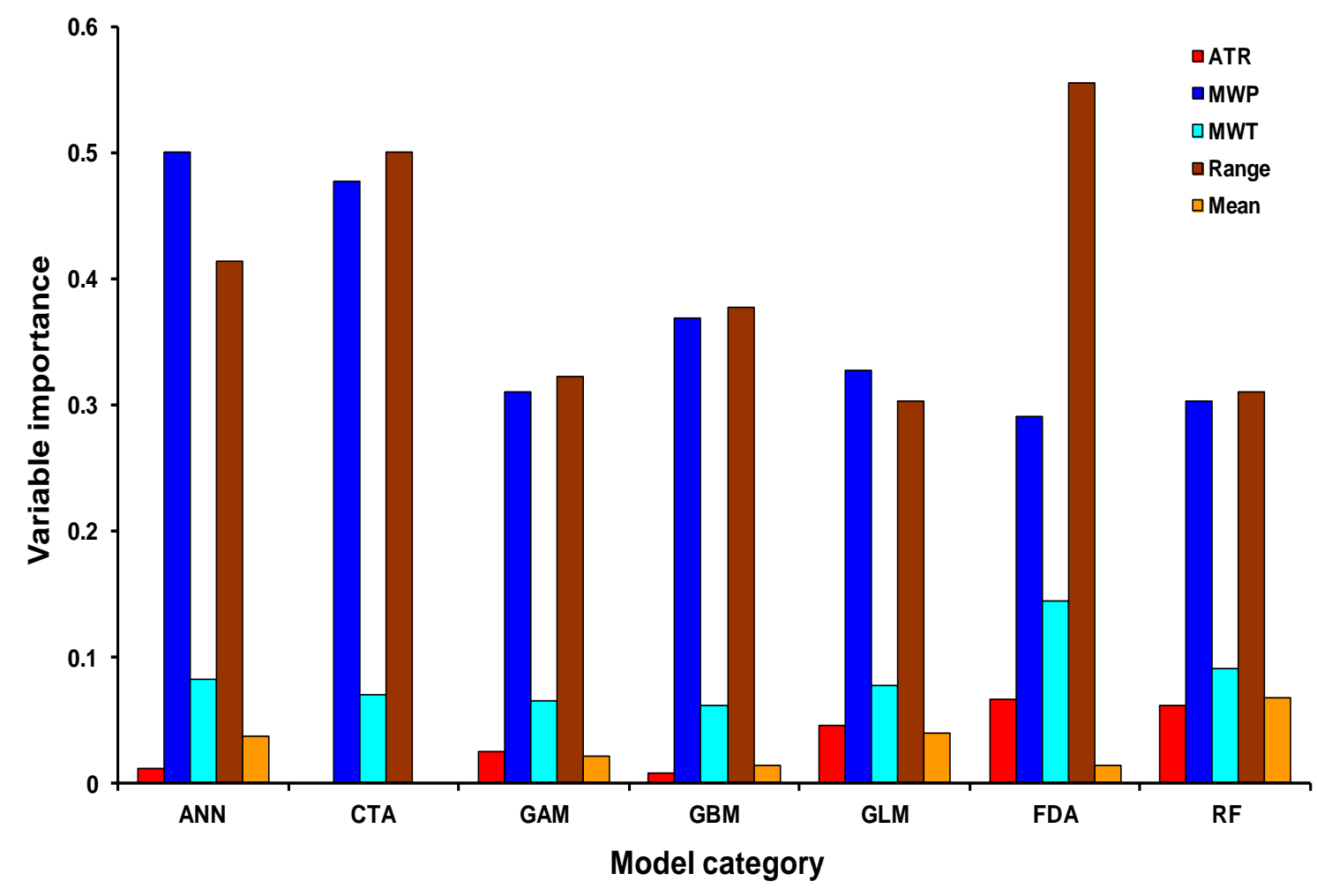

Figure 3: Relative importance of the variables used to model the active blanket bog distribution. Variable importance was calculated as 1 minus the correlation between the standard prediction and the prediction where the considered variable was randomised. ATR: annual temperature range, MWP/MWT: mean winter precipitation/temperature, Range: elevation range, Mean: mean elevation. See Table 1 for model acronyms 


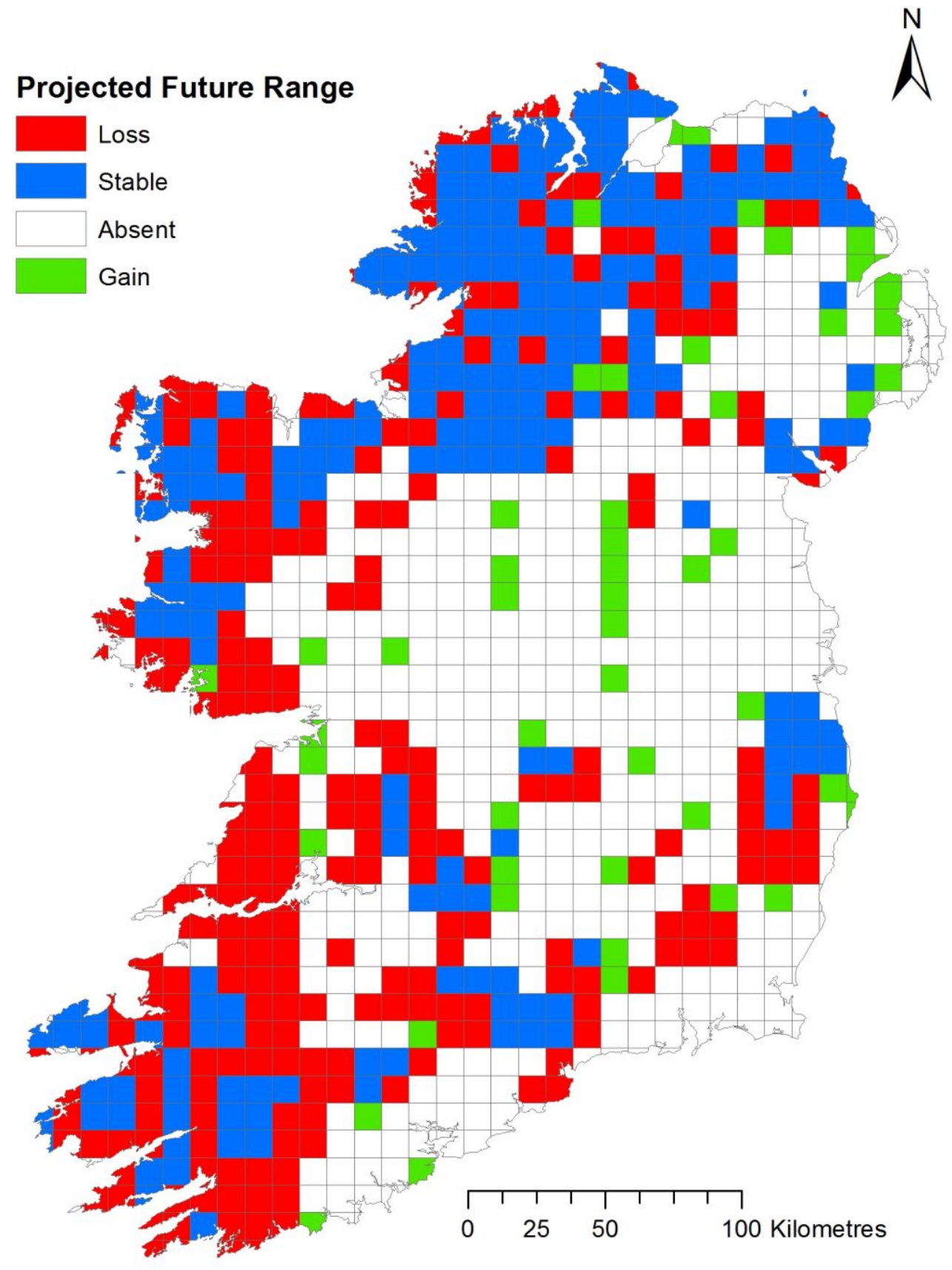

Figure 4: Mapped BIOMOD consensus model output for the active blanket bog habitat based on a Principal Components Analysis (PCA) of the median probability values and the True Skill Statistic (TSS) threshold. Red squares: projected losses of climate space for the A1B 2031-2060 scenario relative to the baseline; blue squares: stable climate space grids; green squares: potential climate space gains relative to the baseline 

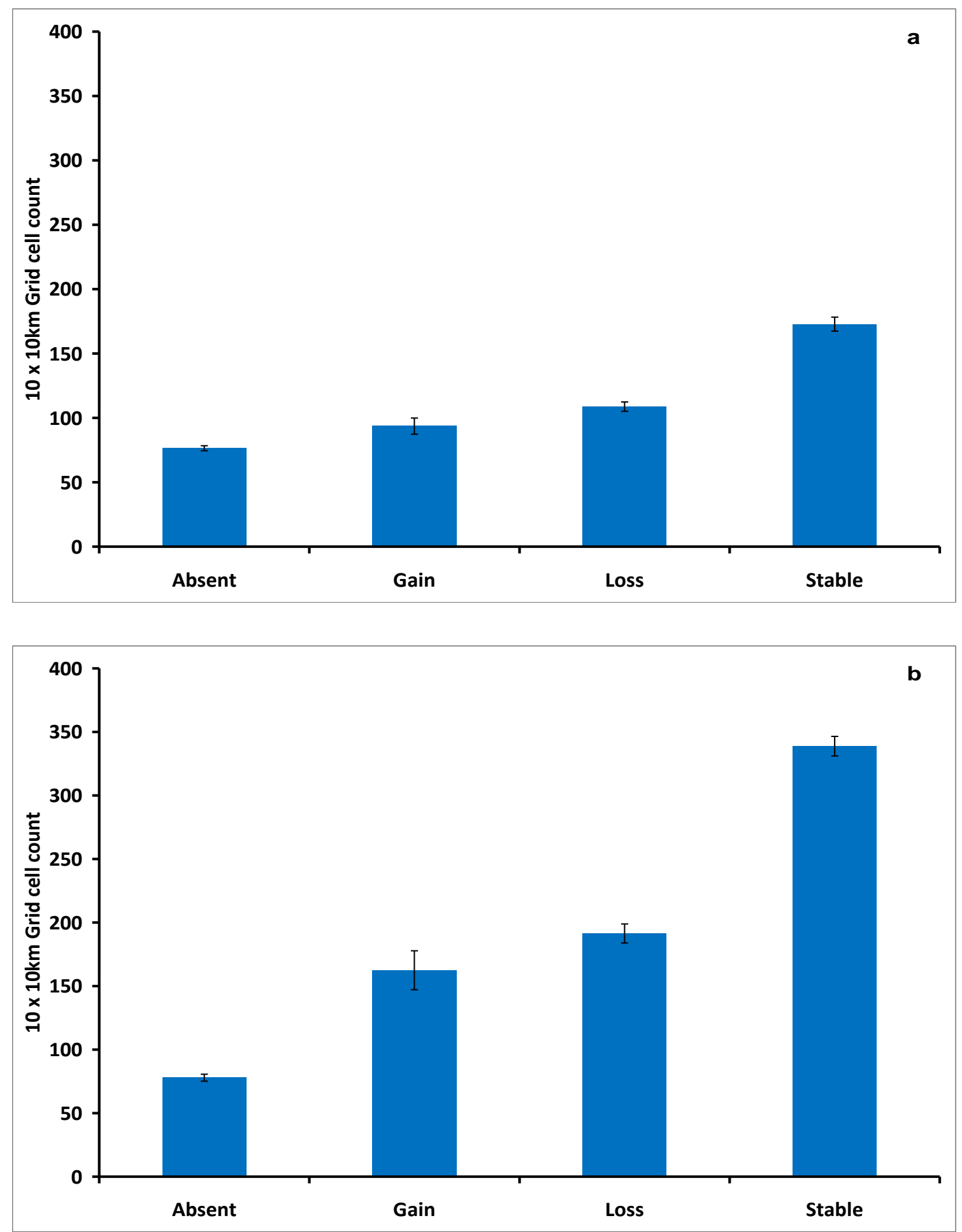

Figure 5: BIOMOD consensus model projected absent, gain, loss and stable summary count matched to the (a) the mean elevation and (b) the elevation range of the $10 \times 10$ km grid cells. Vertical bars: +/- SE. 


\section{Tables}

Table 1. Summary comparison of model evaluation statistics with respect to the 7 BIOMOD modelling techniques used. TSS: true skill statistic; Kappa: Cohen's Kappa; AUC: area under the curve. GLM: generalized linear models; GAM: generalized additive models; ANN: artificial neural networks; GBM: general boosting method; RF: random forests; CTA: classification tree analysis; FDA: flexible discriminant analysis; CONSENSUS: BIOMOD consensus model weighted values

\begin{tabular}{llll}
\hline Model category & TSS & Kappa & AUC \\
\hline GLM & 0.768 & 0.767 & 0.942 \\
GAM & 0.757 & 0.757 & 0.941 \\
ANN & 0.711 & 0.711 & 0.930 \\
GBM & 0.765 & 0.764 & 0.944 \\
RF & 0.755 & 0.754 & 0.942 \\
CTA & 0.753 & 0.753 & 0.915 \\
FDA & 0.742 & 0.743 & 0.936 \\
CONSENSUS & 0.978 & 0.978 & 0.976 \\
\hline
\end{tabular}

Table 2. Summary comparison of individual model baseline prediction calls and projected changes in climate space associated with the A1B 2031-2060 climate scenario data applied for each $10 \times 10 \mathrm{~km}$ grid square. MEAN: average of the 7 model categories (grid cell counts rounded to nearest whole number). See Table 1 for acronyms

\begin{tabular}{lllllllll}
\hline $\begin{array}{l}\text { Model } \\
\text { category }\end{array}$ & $\begin{array}{l}\text { Baseline } \\
\text { Predicted } \\
\text { Presence }\end{array}$ & $\begin{array}{l}\text { Baseline } \\
\text { Predicted } \\
\text { Absence }\end{array}$ & $\begin{array}{l}\text { Climate } \\
\text { Change } \\
\text { Projected } \\
\text { Presence }\end{array}$ & $\begin{array}{l}\text { Climate } \\
\text { Change } \\
\text { Projected } \\
\text { Absence }\end{array}$ & $\begin{array}{l}\text { Projected } \\
\text { Loss }\end{array}$ & $\begin{array}{l}\text { Projected } \\
\text { Stable }\end{array}$ & $\begin{array}{l}\text { Projected } \\
\text { Gain }\end{array}$ & $\begin{array}{l}\% \\
\text { change } \\
\text { from } \\
\text { baseline }\end{array}$ \\
\hline GLM & 487 & 476 & 131 & 832 & 386 & 547 & 30 & -73.1 \\
GAM & 473 & 490 & 266 & 697 & 252 & 666 & 45 & -43.8 \\
ANN & 482 & 481 & 340 & 623 & 196 & 713 & 54 & -29.5 \\
GBM & 513 & 450 & 443 & 520 & 125 & 783 & 55 & -13.6 \\
RF & 491 & 472 & 526 & 437 & 84 & 760 & 119 & +7.1 \\
CTA & 500 & 463 & 577 & 386 & 48 & 790 & 125 & +15.4 \\
FDA & 511 & 452 & 89 & 874 & 450 & 485 & 28 & -82.6 \\
MEAN & 494 & 469 & 339 & 624 & 220 & 678 & 65 & -31.4 \\
\hline
\end{tabular}

